\title{
Using social network sites in Higher Education: An experience in business studies
}

\section{José L. Arquero*, Esteban Romero-Frías}

Department of Accounting and Finance, University of Seville, Seville, Spain.

Correspondence details:

José L. Arquero

Department of Accounting and Finance, University of Seville

C/ Ramón y Cajal, $\mathrm{N}^{\circ} 1$

41018, Seville, Spain

Tel. 34-954557604

Abstract

In the past 5 years the impact of Web 2.0 in new generations has been remarkably significant (Pew Research Center, 2010). This paper reports on an experience in the use of

\footnotetext{
*Corresponding author. Email: arquero@us.es
} 
Arquero, J. L., \& Romero-Frías, E. (2013). Using social network sites in Higher Education: an experience in business studies. Innovations in Education and Teaching International, 50(3), 238-249. Preprint for research purposes

Social Network Sites (SNS) to support student involvement with the subject and to develop basic skills.

According to students' opinion, the experience was deemed as positive. They considered that the experience contributed to a higher engagement with the subject and a deeper collaboration with other students and teaching staff. As a result, the majority of students would prefer the use of SNS as a first option if they had to enrol again in the subject.

Regarding the relationships between academic performance and use of the SNS, two different student profiles were identified based on usage patterns of the platform. Students with a more intensive use of the site showed a significantly better performance than students with a low usage profile.

Keywords: Collaborative learning; Web 2.0; Computer-mediated communication; Learning 2.0; Learning communities; Social Network Sites

\section{Introduction}

The underlying objective of the recent reform of the European university system (European Ministers of Education, 1999) is to facilitate the development of students' competencies in a lifelong learning scenario. The European Commission (2008) highlighted the need for integrating Information and Communication Technologies (ICT) in all levels of education in order to support lifelong learning and innovation. ICT constitutes the most relevant mean to retrieve information and generate knowledge in an information-based society and should enable people to learn in a continuous, autonomous and collaborative way. These ideas are highlighted in the Horizon Report (The New Media Consortium, 2008), which underlines the need for universities to endow students with new media literacy skills and to develop curricula that help students with today's tools. 
Arquero, J. L., \& Romero-Frías, E. (2013). Using social network sites in Higher Education: an experience in business studies. Innovations in Education and Teaching International, 50(3), 238-249. Preprint for research purposes

In our field, the educational standards issued by the International Federation of Accountants (IFAC, 2009) highlighted the need to promote lifelong learning and to change the role of students towards an active involvement in their own learning process (necessary prerequisite for lifelong learning) by fostering creative use of technology and group work. These educational goals and means are endorsed by other professional organisations at a European and US context (Common content project, 2006; AICPA, 2009) and evidenced by recent research (e.g. Hassall, Joyce, Arquero \& Donoso, 2003; Milner \& Hill, 2007).

In one hand, the Pew Research Center (2010) reports that 95\% of "Millennials" in the United States (generation born between 1977 and 1992) go online and that 83\% use SNSs, highlighting the popularity of such services among students. On the other hand, Web2.0 services are remarkably effective in connecting people and in facilitating the exchange of information, providing new opportunities for improving the acquisition of non-technical skills in higher education regardless of the field of knowledge.

From this standpoint, we decided to use a Social Network Site to support student engagement and to develop digital and non-technical skills, essential in any professional field and particularly in Business.

\section{The application of Web 2.0 to education}

\section{A social-constructivist approach}

OSince its creation, the Web has been used for educational purposes. In our field there has been substantial investment in Learning Management Systems (LMSs) such as Blackboard or WebCT in order to offer online courses or enhance offline classes (Watson, Apostolou, Hassell \& Webber, 2007). Web-based materials have also been extensively used in the classrooms. Some research has focused on the results of using these types of platforms (deLange, Suwardy \& Mavondo, 2003; Dunbar, 2004), and in the evaluation of other tools to assist offline classes (Abdolmohammadi, Howe \& Ryack, 2003; Ammons \& Mills, 2003). However, most of this research focused on Web 1.0 tools, which is being pushed into the background by Web 2.0 (O'Reilly, 2005). The significant impact of Web 2.0 is expected to be higher as generations who have grown up in a fully digital environment move from University 
Arquero, J. L., \& Romero-Frías, E. (2013). Using social network sites in Higher Education: an experience in business studies. Innovations in Education and Teaching International, 50(3), 238-249. Preprint for research purposes

into career paths and occupy management positions (Tapscott, 2009). Many voices have claimed a positive impact of Web 2.0 on education (Solomon \& Schrum, 2007; Richardson, 2009). Social software is considered to be effective in developing essential skills (selecting relevant information, critically interpreting and analysing the socio-cultural context, working collaboratively, sharing knowledge, etc.). Nervertheless, as the Report on Learning 2.0 issued by the European Commission (Redecker, Ala-Mutka, Bacigalupo, Ferrari \& Punie, 2010: pp. 102-103) states: 'Research is needed to determine how learning schemes and organisational processes are modified and transformed by Learning 2.0 approaches, which in turn will change assessment and certification, recruitment and the accreditation of E\&T [Education and Technologies] institutions and courses. There is also a need for more scientifically guided experiments and controlled trials and a need for research to highlight policy implications.'

Recent research has looked into social constructivism as a way to interpret and assess some of the potential benefits of Web 2.0 in education (Sturm, Kennell, McBride \& Kelly, 2009). The learners' need to create meaning requires a balance between (a) autonomy (Jonassen, 1991), and (b) community (Duffy \& Cunningham, 1996). SNSs tend to be, by their nature, collaborative, although the main focus is not on the creation of content but on the development of users' identities and the collaboration between them. Social constructivism situates learning in communities of learning and practice (Brown \& Adler, 2008). Individuals have the autonomy to create and express themselves online, to author their own content, and to share that content with others in efficient and meaningful ways.

\section{SNS: concept and relevance}

Boyd and Ellison (2008, p. 211) define SNSs as "web-based services that allow individuals to (1) construct a public or semi-public profile within a bounded system, (2) articulate a list of other users with whom they share a connection, and (3) view and traverse their list of connections and those made by others within the system". SNSs are currently the most popular type of social software because they facilitate the combined usage of many Web 2.0 technologies into platforms that work as virtual gathering places for social interactions.

The rise of SNSs indicates a shift in the organization of online communities (Boyd \& Ellison, 2008). Unlike Websites dedicated to communities of interest, SNSs are primarily organized around people. Halvorsen (2009) remarks on their efficiency in allowing users to 4 
Arquero, J. L., \& Romero-Frías, E. (2013). Using social network sites in Higher Education: an experience in business studies. Innovations in Education and Teaching International, 50(3), 238-249. Preprint for research purposes

share information and interact with one another in a dynamic and multi-modal environment. SNSs seem to fill the lack of face-to-face interaction in some contexts of today's modern society.

As University students are high profile users of SNS, scholars are documenting the implications of SNS use in academic contexts: Hewitt and Forte (2006) examined how students feel about having teachers on Facebook; Mazer, Murphy and Simonds (2007) how faculty participation affects student-teaching staff relations, and Ellison, Steinfield and Lampe (2007) focused on the relationship between the use of Facebook and the formation and maintenance of social capital.

\section{Objectives and research questions}

Given the apparent synergy between the technological characteristics of SNSs and the models of learning being actively promoted in European Higher Education, the main research questions are:

- Does the innovation improve contents learning?

- Has the innovation impact in the development of critical thinking?

- Does the innovation enhance the active involvement of the students in the learning process?

- Does the innovation promote group work and collaborative learning?

The project was implemented in an optional course on International Accounting, taught in the last years of the Degree in Business Administration at the University of Granada (Spain). The changing nature of the subject requires that students develop some expertise to keep their technical knowledge up-to-date and their critical thinking and communication skills active. In order to achieve the combined development of contents and skills, the use of SNS promotes social interaction and a higher exposure to business environment.

\section{Method}

Description of the platform 
Arquero, J. L., \& Romero-Frías, E. (2013). Using social network sites in Higher Education: an experience in business studies. Innovations in Education and Teaching International, 50(3), 238-249. Preprint for research purposes

A private SNS was created by using the platform Ning (http://www.ning.com/). This service allows creating a protected space of interaction where only the students voluntarily could participate. Teachers and students willing to participate accepted the terms of use of Ning. This fact, together with the use of quantitative data of SNS use with research purposes, was underlined at the beginning of the course. Although students could opt out of the activity, all 160 students enrolled registered in the SNS.

We decided to use a publicly available and general-purpose SNS service instead of an institutional LMS because the former integrates a set of tools that are open for use by students through their professional careers whereas the latter constitutes a closed platform which is only useful during their students' life. Some of the main tools implemented in the SNS included chat, discussion forums, RSS feed, blogs, Google docs, etc.

During the first two weeks of the course, students received explanations about the nature of SNS, its pedagogical applications and the usage of the main tools. Students were explained that, although SNS were not designed for educational purposes, the experience intended to illustrate how these services, which were extremely popular among them, could be used as a powerful tool for educational purposes and later on in their professional career (whereas LMSs are restricted to be used only within the educational institution). No other intentions (such as the development of collaborative or critical skills) were shared with the students, in order to avoid any influence in their responses.

The tasks in the SNS assigned to the students for the course included: sharing links with relevant information, selecting pieces of news, analysing those news critically, and adding comments to the forum. Task were done by students voluntarily and had a positive impact in the final mark of the course, however not participating in this activities did not undermine the possibilities to obtain the highest mark through final examination. The aforementioned are some of the tasks proposed by the teachers; however, students were free to participate in the SNS in any way they consider appropriate. In this regard, online and offline participation in the course were considered at the same level. 
Arquero, J. L., \& Romero-Frías, E. (2013). Using social network sites in Higher Education: an experience in business studies. Innovations in Education and Teaching International, 50(3), 238-249. Preprint for research purposes

\section{Data collection and analysis}

At the end of the course a questionnaire was distributed among the students through the SNS.

The questionnaire included items in the following categories

1. Personal data

2. Digital literacy and perceived difficulty of use

3. Effects of the innovation on:
a. active role,
b. collaborative learning,
c. critical thinking, and
d. content learning

4. General assessment

Assessment items (categories 3 and 4) were designed to be answered in a 5-point Likert scale, ranging from 1 (complete disagreement) to 5 (complete agreement), 3 being neutral opinion.

A database, containing the different grades obtained by the students, was created. The total grade was a composite of the final exam grade, the completion of an essay and the participation and completion of minor tasks in the daily class. The participation on the SNS was considered in the last item as an additional positive mark that could increase the examination and essay marks. Students who didn't participate in the class or in the SNS could also obtain the highest mark through the completion of examination and essay.

In addition, the SNS provided information about the level of active participation by students. Given the tasks to perform, the following variables indicate the level of participation and involvement in the activities done in the SNS:

- Number of comments in blogs and forum (showing the level of response to teachers and other students' contents);

- Number of discussions created in their own blog and forum (showing the level of initiative to propose new subjects and issues to discuss); and 
Arquero, J. L., \& Romero-Frías, E. (2013). Using social network sites in Higher Education: an experience in business studies. Innovations in Education and Teaching International, 50(3), 238-249. Preprint for research purposes

- Number of contacts of each student (showing the level of social interaction between students).

\section{Results}

\section{Descriptive data}

A total of 105 questionnaires, out of 160 registered students, were gathered. Students were not allowed to leave assessment questions in blank; therefore, all the percentages are calculated over the same $\mathrm{n}(105)$. The age of the respondents ranged from 19 to 32, with a mean of 22; almost $68 \%$ were female.

The frequency of Internet access was high: close to $87 \%$ of students accessed at least once a day. The vast majority of them used their own computer for this purpose (71\% laptops vs $29 \%$ desk computers), either at their homes during the week (82\%), or at the university (12\%). More than $86 \%$ were active users of SNS prior to the experience and only $12 \%$ rated their ability to use Internet tools as "low".

In general terms, the respondents did not indicate great difficulties in any of the aspects evaluated (Table 1). Scoring from 0 (no difficulty at all) to 10; the means of the perceived difficulty are lower than 2.5 .

Inset table 1 about here.

\section{Increasing the active role of students}

Lifelong learning requires from students to be able to learn on their own and to be active participants on their learning process. In these terms, the opinion of the students indicates that the use of the SNS has been fairly successful (table 2). More than $88 \%$ of the students stated that using the SNS as a learning tool motivated them to get more actively involved than with a traditional pedagogy; close to $83 \%$ believe that is also useful to keep their professional knowledge up to date.

Insert table 2 about here. 
Arquero, J. L., \& Romero-Frías, E. (2013). Using social network sites in Higher Education: an experience in business studies. Innovations in Education and Teaching International, 50(3), 238-249. Preprint for research purposes

Flexibility is greatly appreciated by students: $93 \%$ agreed that the use of the SNS allows them to better manage their time to study for the subject; $99 \%$ indicated that is a flexible way to approach the teaching staff. This flexibility is expected to help the autonomy of the students.

\section{Collaborative learning}

In terms of collaborative learning and team working, the SNS seems to be a helpful learning tool (table 3). The positive aspects of sharing ideas and points of view among students are highly rated.

Insert table 3 about here.

The benefits derived from the dissemination of ideas and points of view are highly rated as one of the major advantages of the use of the SNS. The respondents also considered the SNS as a useful tool to facilitate team working and coordinate actions.

\section{Promoting critical thinking}

As indicated previously, SNS facilitates the interaction between students. The access to different points of view widens and enriches their knowledge on contents by developing a critical attitude towards opinions. In this line, the respondents indicated that the experience helped them to develop a more critical and reflective attitude towards the content of the subject ( $81 \%$ agreement; table 4), the contents accessible via Internet (71\%) and the opinions of their peers $(74 \%)$. ।

Insert table 4 about here.

Critical thinking and communicative skills are basic to achieve successful collaborative learning; therefore, an appropriate environment to promote students contributions is required. According to responses, 67\% report that the use of SNS allows them to express their opinions and views more freely than in the classroom. This aspect leaves the door open for the usage of SNS as a complement of traditional classroom learning, becoming, thus, a communication barrier breaker (for instance gender differences and limitations of disabled students). 
Arquero, J. L., \& Romero-Frías, E. (2013). Using social network sites in Higher Education: an experience in business studies. Innovations in Education and Teaching International, 50(3), 238-249. Preprint for research purposes

\section{Content learning}

In the end, the development of the desired capabilities and content learning is the underlying aim of any educational innovation. Given that all students participated in the activity, the relationship performance - participation is assessed by (I) the opinion of students and (II) by comparing the real performance of students that were more actively engaged in the innovation versus those students that, although participating, were more passive.

The opinions of the students are indicative of a positive effect (table 5). More than 95\% agreed that the use of the SNS was useful for the learning of the technical contents of the course (versus $0 \%$ of disagreement). Although not so high, the new digital context also motivated students to work harder in the subject (58\% of agreement) and even to increase their interest in it (53\% of agreement).

\section{Insert table 5 about here}

A cluster analysis was performed to classify the students by their level of participation in the activity. The variables used in the cluster analysis were related to the number of comments in blogs and in forum, the number of discussions created in their own blog and forum, and the number of contacts each student established in the SNS. Two clusters were defined (table 6):

\section{Insert table 6 about here}

Students indicated in the questionnaire the grades obtained in previous Accounting courses. This variable was used as a measure of academic performance to control for previous differences in performance between the two groups. The results indicate that there were no significant differences on previous performance between groups by participation (Chi square test).

Comparing the results of the present subject, the comparison of academic performance by participation (table 7) reveals that students participating more actively in the SNS tend to obtain higher grades in all the measures.

Insert table 7 about here. 
Arquero, J. L., \& Romero-Frías, E. (2013). Using social network sites in Higher Education: an experience in business studies. Innovations in Education and Teaching International, 50(3), 238-249. Preprint for research purposes

The results indicate that students participating more actively in the innovation, although similar in previous performance measures, obtain significantly higher grades in what we could call the continuous evaluation and assessment measures. There is no significant difference in the exam marks, although the mean of the second group is higher. When all the three measures are combined into the final grade, high participation group obtains almost 1.5 points more in the final mark. These results are indicative of a positive effect of the innovation on content learning.

\section{General assessment}

In terms of general assessment, the results are encouraging: $91 \%$ of students agreed with the positive impact of the use of SNSs for educational purposes in the quality of the learning and teaching process at university level. Close to $96 \%$ of students would recommend their colleagues to enrol in the course. In fact, close to $94 \%$ of the students indicate that the generalised use of an integrated SNS for all courses could be an effective learning tool (table 8).

\section{Insert Table 8 here-.}

Finally, students did not remark difficulty of use of the SNS as a constraint or de-motivating factor (around 7\% of agreement versus $86 \%$ of disagreement).

However, significant differences in the general assessment arose depending on previous experiences with SNSs (table 8table9). Students with previous experience indicated a significantly higher level of agreement with the benefits of SNSs as a learning tool. In any case, results are still very positive with respect to the experiment and no differences were found in the possible de-motivation for its use.

\section{Concluding remarks}

The degree of students' usage of the Internet supports the appropriateness of the project. According to the survey, a vast majority of students go online daily, using their own devices, mainly laptops. Therefore, the digital divide (Redecker et al., 2010) concerning Internet 
Arquero, J. L., \& Romero-Frías, E. (2013). Using social network sites in Higher Education: an experience in business studies. Innovations in Education and Teaching International, 50(3), 238-249. Preprint for research purposes

access is not a serious drawback for the project; at least not as much as the difficulties related to attending traditional courses.

In relation to the aims of the experience, the results indicate positive effects. In general terms, the experience was positively valued by students, who agreed that the SNS as used in the experience was a good learning tool whose generalisation could improve the quality of learning at university level. This result, as implication, leaves the door open for the transference of the experience to other knowledge areas and courses, as well as for the creation of an integrated environment for different subjects. Even the students who were not used to implement or create web-content did not perceive the SNS as difficult to use. However, previous experience with similar software has some influence in both, the assessment of the activity and the perceived difficulty. This result leads to the training issue (Cole, 2009): the familiarity of all the actors (students and teaching staff) with the platforms and the work dynamics is a key factor for success in this kind of experiences. Therefore, although students report high degrees of comfort and familiarity with using SNS and other Web 2.0 tools, a period of previous training, for both students and teachers, could foster the results.

Most of the respondents considered that the use of the SNS allowed them to use helpful tools to keep their knowledge up-to-date in a lifelong learning context. In this line, the use of cost-free general-purpose Web 2.0 tools has two main advantages: are open for use by students through their professional careers (whereas LMSs constitutes a closed platform which is only useful during their students' life) and allows shifting the allocation of economic resources towards a more creative task other than the design and maintenance of the software (Mompo \& Redoli, 2010). The use of public available software does not undermine ownership of student work in the same way that, for instance, publishing in a public blog platform does not imply loosing the content by the author. The use of public software allows exploiting the potential of spreading ideas and public participation. Although, it is important to raise concern about the terms of use of the services we use, this issue also applies to institutional systems.

With no opposing opinions, the use of the SNS was viewed as useful for content learning. This is mainly achieved through a combination of autonomy, flexibility and 
Arquero, J. L., \& Romero-Frías, E. (2013). Using social network sites in Higher Education: an experience in business studies. Innovations in Education and Teaching International, 50(3), 238-249. Preprint for research purposes

collaboration which allows for information exchange with peers and creation of a shared knowledge ground. Students agreed with the positive effects of accessing others' points of view, of sharing ideas and collaborating with peers (as held by social constructivist views). The possibility to access the teaching staff and other students at any time and from any location was also highly valued. The easier access to different ideas, and the possibility to comment on them in an open minded environment, had also a positive effect in promoting the critical view of students towards contents, resources and opinions. Given the information overload to which students are exposed on the Internet today, the issue is of special importance because it makes the ability to filter contents a key competence in current and future educational and professional contexts.

Finally, when comparing performance, students more actively involved in the experience tend to obtain higher grades, although no performance differences a priori were found. Those differences were not significant for the exam (more rigid and focused only in content) but they were for the essay, where students could put into practice acquired skills in a more complex way.

\section{Limitations}

As we tried not to exclude students from the experience, no control group exists; therefore, results should be interpreted with caution.

The experience requires a high level of compromise by the teaching staff in order to obtain the desired results.

\section{Acknowledgements}

This work was partially supported by the Junta de Andalucía - FEDER (Proyectos de Excelencia: SEJ-02670)

\section{Notes on contributors}

Dr. Esteban Romero-Frías is assistant professor at the Department of Finance and Accounting at the University of Granada. He carries out research in two main fields: (1) the 
Arquero, J. L., \& Romero-Frías, E. (2013). Using social network sites in Higher Education: an experience in business studies. Innovations in Education and Teaching International, 50(3), 238-249. Preprint for research purposes

application of Webometric techniques to business, and (2) the impact of Web 2.0 in higher education. Since 2007, he uses blogs, wikis and social networks in his courses. He coordinated innovative learning projects based on Web 2.0 tools at the University of Granada. He visited different research centers in Canada, Mexico, United Kingdom, The Netherlands and France. In 2011 he visited the Centre de Recherche Interdisciplinaire (CRI) at Université Paris Descartes in Paris, a center that works in implementing games in teaching and research.

Dr. José L. Arquero, is member of the Accounting and Finance Department at the University of Seville. His main research area is accounting education, field where he obtained the extraordinary doctoral award and has published extensively. From those outcomes, we could highlight papers in the European Accounting Review, Accounting Forum, Accounting Education, Innovations in Education and Teaching International, Industry \& Higher Education, Education \& Training, Higher Education in Europe or the Journal of Vocational Education \& Training. He is the editor of EDUCADE: the Spanish Journal of Accounting, Finance and Management Education 
Arquero, J. L., \& Romero-Frías, E. (2013). Using social network sites in Higher Education: an experience in business studies. Innovations in Education and Teaching International, 50(3), 238-249. Preprint for research purposes

\section{References}

Abdolmohammadi, M., Howe, M., \& Ryack, K. (2003). Students' perceptions of learning in a web-assisted accounting course: Determinants of student motivation. Accounting Education, 12(1), 1-14.

American Institute of Certified Public Accountants (2009). Mapping of the core competency framework to the skills tested on the CPA exam. Retrieved August 7, 2009, from AICPA Website: http://ceae.aicpa.org/Resources/Education+and+Curriculum+Development

Ammons, J. L., \& Mills, S. K. (2003). Learners as designers of educational hypermedia in accounting. Advances in Accounting Education, 5(1), 1-25.

Boyd, D. M., \& Ellison, N. B. (2008). Social network sites: Definition, history, and scholarship. Journal of Computer-Mediated Communication, 13(1), 210-230.

Brown, J. S., \& Adler, R. P. (2008). Minds on fire: Open education, the long tail, and learning 2.0. Educause Review, 43(1), 16-32. Retrieved August 7, 2009, from Educase website: http://www.educause.edu/ir/library/pdf/ERM0811.pdf

Cole, M. (2009). Using Wiki technology to support student engagement: Lessons from the trenches. Computers \& Education, 52(1), 141-146.

Common Content Project (2006). Skills framework. Retrieved August 7, 2009, from Common Content Project website: http://www.commoncontent.com/files/projectdocuments_file-5.pdf

deLange, P., Suwardy, T., \& Mavondo, F. (2003). Integrating a virtual learning environment into an introductory financial statement analysis course. Advances in Accounting Education, 5(1), 181-197.

Duffy, T. M., \& Cunningham, D. J. (1996). Constructivism: Implications for the design and delivery of instruction. In D. H. Jonassen (Ed.), Handbook of research for educational communications technology (pp. 170-198). New York: Simon \& Schuster Macmillan.

Dunbar, A. E. (2004). Genesis of an online course. Issues in Accounting Education, 19(3), 321-343. 
Arquero, J. L., \& Romero-Frías, E. (2013). Using social network sites in Higher Education: an experience in business studies. Innovations in Education and Teaching International, 50(3), 238-249. Preprint for research purposes

Ellison, N. B., Steinfield, C., \& Lampe, C. (2007). The benefits of Facebook “friends": Social capital and college students' use of online social network sites. Journal of ComputedMediated Communication, 12(4), 1143-1168.

European Commission (2008). The use of ICT to support innovation and lifelong learning for all - A report on progress. Brussels: European Commission. Retrieved July 31, 2009, from European Commission website: http://ec.europa.eu/education/lifelong-learningprogramme/doc/sec2629.pdf

European Ministers of Education (1999). The Bologna Declaration of 19 June 1999 - Joint declaration of the European Ministers of Education. Retrieved 15 March 2011 from http://www.ond.vlaanderen.be/hogeronderwijs/bologna/documents/MDC/BOLOGNA _DECLARATION1.pdf

Halvorsen, A. (2009). Social networking sites and critical language learning. In M. Thomas (ed.), Handbook of research on web 2.0 and second language learning (pp. 237-258). Hershey, PA: Information Science Reference.

Hassall, T., Joyce, J., Arquero, J. L., \& Donoso, J.A. (2003). The Vocational skills gap for management accountants: The stakeholders perspectives. Innovations in Education and Teaching International, 40(1), 78-88.

Hewitt, A., \& Forte, A. (2006). Crossing boundaries: Identity management and student/faculty relationships on the Facebook. Poster presented at CSCW, Banff, Alberta.

International Federation of Accountants (IFAC) - Accounting Education Standards Board (IAESB) (2009). Handbook Of international education pronouncements. New York: IFAC.

Jonassen, D. H. (1991). Objectivism versus constructivism: Do we need a philosophical paradigm? Educational Technology Research and Development, 39(3), 5-14. 
Arquero, J. L., \& Romero-Frías, E. (2013). Using social network sites in Higher Education: an experience in business studies. Innovations in Education and Teaching International, 50(3), 238-249. Preprint for research purposes

Mazer, J. P., Murphy, R. E., \& Simonds, C. J. (2007). I'll see you on 'FFacebook:' The effects of computer-mediated teacher self-disclosure on student motivation, affective learning, and classroom climate. Communication Education, 56(1), 1-17.

Mompo, R., \& Redoli, J. (2010) Some Internet-based strategies that help solve the problem of teaching large groups of engineering students. Innovations in Education and Teaching International, 47(1), 95-102.

Milner, M. M., \& Hill, W. Y. (2007). Examining the skills debate in Scotland. The International Journal of Management Education, 6(3), 13-31.

O'Reilly, T. (2005). What is Web 2.0: Design Patterns and Business Models for the Next Generation of Software. Retrieved 20 March 2011 from: http://oreilly.com/web2/archive/what-is-web-20.html

Pew Research Center (2010). Generations 2010. Retrieved February 14, 2011, from Pew Research Center : http://pewinternet.org/Reports/2010/Generations-2010.aspx

Redecker, C., Ala-Mutka, K., Bacigalupo, M., Ferrari, A., \& Punie, Y. (2010) Learning 2.0: The Impact of web 2.0 Innovations on education and training in Europe (Final Report). Institute for prospective technological studies. European Commission. Retrieved 15 March 2011 from: http://ftp.jrc.es/EURdoc/JRC55629.pdf

Richardson, W. (2006). Blogs, Wikis, podcasts, and other powerful tools for classrooms. Thousand Oaks, CA: Corwin Press.

Solomon, G., \& Schrum, L. (2007). Web 2.0: New tools, new schools. Eugene, OR: International Society for Technology in Education.

Sturm, M., Kennell, T., McBride, R., \& Kelly, M. (2009). The pedagogical implications of web 2.0. In M. Thomas (ed.), Handbook of research on web 2.0 and second language learning (pp. 367-384). Hershey, PA: Information Science Reference.

Tapscott, D. (2009). Grown up digital: How the net generation is changing your world. New York: McGraw-Hill. 
The New Media Consortium / The EDUCASE Learning Initiative (2008). The horizon report: 2008 edition. Austin, TX: The New Media Consortium. Retrieved February 16, 2009, from The New Media Consortium: http://www.nmc.org/pdf/2008-Horizon-Report.pdf

Watson, S. F., Apostolou, B., Hassell, J. M., \& Webber, S. A. (2007). Accounting education literature review (2003-2005). Journal of Accounting Education, 25(1), 1-58. 
Table 8. General assessment of the activity.

\begin{tabular}{|c|c|c|c|c|c|c|}
\hline & \multicolumn{3}{|c|}{ Descriptives } & \multicolumn{3}{|c|}{ Previous experience } \\
\hline & Mean & Agreem. & Disagreem. & No & Yes & t-test sig. \\
\hline I'd recommend to other students to enrol in the subject. & 4.39 & $95.92 \%$ & $1.02 \%$ & 4.31 & 4.39 & n.s. \\
\hline $\begin{array}{l}\text { I think that the generalisation of these initiatives could } \\
\text { improve significantly the quality of learning at university } \\
\text { level. }\end{array}$ & 4.28 & $91.09 \%$ & $2.97 \%$ & 3.54 & 4.38 & .000 \\
\hline $\begin{array}{l}\text { An integrated SNS for all the subjects, or similar subjects, } \\
\text { could be a good learning tool. }\end{array}$ & 4.26 & $93.88 \%$ & $5.10 \%$ & 3.75 & 4.36 & .004 \\
\hline The difficulties to use the SNS de-motivate me to use it. & 1.71 & $6.80 \%$ & $86.41 \%$ & 1.70 & 1.71 & n.s. \\
\hline
\end{tabular}

